\title{
Tourism development in protected areas: A case study of Al-Moez Street in Cairo
}

\author{
Nashaat Essayed Mortada, Farouk Abdel-Naby Hassanein* and Susan Bakry Hasan \\ Faculty of Tourism and Hotels, Fayoum University, Cairo, Egypt.
}

Accepted 1 September, 2010

\begin{abstract}
Nature reserves are a means of conserving natural and cultural treasures which if lost, can never be restored for its importance. Several international organizations cater for nature reserves. In 1966, the Tourism and Conservation Authority was established. It belongs to the International Union for Conservation of Nature (IUCN) which caters for nature reserves and their management. With the growing attention being paid to the environment, the year 2002 was declared the 'International Year of Tourism and Environment', in accordance with a decision taken by the Economic and Social Council of the United Nations in 1998. Later on, this decision was approved of by the General Assembly of the United Nations. The problem expounded in this study is the wide gulf between theory and practice when a certain area is declared 'protected'. An example is the 'Nile Islets' which were declared a nature reserve in accordance with a political decree that was not based on any environmental survey or study of the area. Moreover, the classification of protected areas in Egypt is not accurately defined. There is considerable overlap between protected areas, and it is evident that most of them suffer from lack of organization, management and protection. Many important historical, archaeological and rich cultural heritage sites in Egypt suffer remarkable deterioration. Some have completely fallen apart, and some have vanished or have being sacrificed to the bulldozer. This research aims at: (1) deciding the criteria and considerations required to declare a certain area 'a nature or cultural reserve' and the comprehensive tourism development needed; (2) evaluating the current condition (status quo) in the protected area of Al-Moez Street in Cairo. The methodology used in this research work includes: (1) The descriptive analytical method, (2) case study method, (3) survey method, (4) deductive method, and (5) analysis of the primary and secondary data related to the field of study using the statistical program SPSS - V - 11. Research findings have revealed that the criteria and principles of the sustainability of urban and tourism development of Al-Moez Street have been taken into consideration to a reasonable extent. This is also confirmed by the findings of the statistical analysis and the positive and negative aspects that have been observed by a team who paid frequent visits to the area.
\end{abstract}

Key words: Cultural tourism, protected area, criteria of protected area.

\section{INTRODUCTION}

Due to the vital importance of natural and cultural heritage and the necessity to conserve it, international conservation organizations such as the International Union for Conservation of Nature (ICUN), the United Nations Environment Program (UNEP), the World Wild Fund (WWF), and the United Nations Education, Sciences, and Cultures Organization (UNESCO) were established. These organizations embrace governmental

*Corresponding author. E-mail: faroukttllh@yahoo.com. and non-governmental bodies which try to conserve and promote the treasures of nature and assure their sustainability for posterity. They also seek to increase the environmental awareness of people in different countries and cater for the organization and management of nature reserves. Many countries have signed several international agreements to preserve the world's natural and cultural heritage and diversified wildlife; such as the Bonn agreement in 1979 (Ali, 2001; p 79).

In Egypt, the concepts of conserving natural resources and maintaining environmental activities in the ecosystem are in fact a sound reaction to the far-reaching impact of 
population explosion and technological revolution which damage the environment and deplete its resources. The aims of establishing nature reserves should not be confined to conserving natural resources as these reserves should be exploited as economic projects that can possibly generate considerable profit to cover at least some of the running expenses. The gates of the reserves should be open to people to avail themselves of their varied benefits and defend their existence, development and sustainability (Mohamed, 2007).

Cultural tourism is one of the most important fields of conventional tourism through which individuals attempt to get acquainted with new things and widen their knowledge and culture by visiting foreign countries, cities or sites in their own country or abroad in order to know the characteristics of their people, their arts and crafts, their products, customs, traditions and industries through visits to historical and archaeological sites, museums, participating in cultural activities, carnivals, festivals, enjoying various shows and performances available (such as folklore dancing, singing and music) and sharing the local people's way of life (Ali, 2008).

The main concept of our research springs from the fact that conserving our cultural heritage is a national duty and a necessity to maintain the cultural identity of society in view of the prevalent conception of globalization. Cultural identity can be regarded as an important source of tourism if it is well-preserved and displayed in conformity with international criteria. The research also takes into consideration the aims of the Arab Institute for the Development of Cities, to maintain their Arab identity and preserve their cultural heritage.

\section{CRITERIA FOR DEFINIG NATURAL AND CULTURAL RESERVES}

\section{Conditions and specifications}

Several conditions and specifications must be available to declare an area 'a nature reserve' (Ghada, 2003).

1. The area should have a distinguished ecosystem (diversity of fauna and flora).

2. Geophysical factors such as geological areas and natural springs must be present.

3. The area should be of special importance to ecotourism.

4. The availability of archaeological sites.

5. The area should be important to long-term scientific researches.

6. If the area is in need of protection because of some hydrological factors such as the soil, water, local climate, etc.

\section{Dimensions used for defining protected areas}

Sherman and Dixon (1997) refer to the different dimensions used to define nature and cultural reserves and are summed up as follows:

\section{Economic dimension}

Nature reserves are plots of land allotted for purposes different from those used for ordinary human purposes. They usually require tremendous expenditure to perform their function. It is therefore necessary to have strong justifications to designate an area as a nature or cultural reserve in order to convince different categories of the public of its importance for development. The establishment and maintenance of these protected areas constitute heavy economic burdens on developing countries. Moreover, these countries are in many cases incapable of designing protected areas and providing them with infrastructure and essential services. Devising plans and programs to develop these areas also require considerable financial resources which are not available. Developing countries also lack qualified and well-trained administrative personnel capable of running these areas. It is also true that if the revenue generated by these areas is limited, economists and investors decline to participate, but if the revenue is substantial, it would be easy to make decisions for the selection of locations and designating them as protected.

Protected areas - highly desirable -assuredly generate profit, though they sometimes vary considerably. Some of them generate profit after a considerable length of time; others, after a short time. It is therefore possible for businessmen, economists and investors to participate in making decisions for the selection of the locations of protected areas.

\section{Political dimension}

Pressures for the establishment of protected areas are exercised by groups, either from within the country, such as universities, researchers, local communities, environment protection societies, the media and political parties, or bodies outside the country such as foreign governments and international organizations. A well-known case is that of Borollos Lake in the north east of the Delta, which was declared a nature reserve in 1998, in the aftermath of serious environmental degradation and the pressures of local community, mass media and researchers.

It is noticed that advocates of establishing nature reserves are usually met with opposition from owners of industries which depend on the natural resources in these areas, or from other groups that desire to exploit them for their own benefit and depend on the enormity of their political pressure. In developing countries such opposition groups have close relations with decision makers, and consequently can stand against the establishment of protected areas. In the absence of any 
opposition, protected areas are encouraged to continue and flourish. A budget is allotted to them and their activities are defined.

Literature refers to the fact that politics interferes with reaching decisions concerning environment, particularly the selection and definition of nature reserves. However, previous studies indicate that political factor has a weaker impact than economic factor. Economic analysis of the direct and indirect benefits of protected areas is a very influential tool in defining areas suggested to be nature reserves.

\section{CRITERIA USED FOR DEFINING PROTECTED AREAS}

Certain criteria are implicit from legislations used for the selection of protected areas in some countries such as United Kingdom, Canada, and Egypt; which furthermore are an evolution of each other and all approved of by IUCN. These conditions are stated as follows (Ratcliff, 1977; Eagle, 1984; Hend, 2000; Ghada, 2007).

1. Uniformity or discrepancy in land shape and type: This is often decided by geologists and soil scientists who are interested in the distinguishing physical features of the location and its terrain including high mountains, sand dunes, slopes of mountains, etc.

2. Importance of environmental activities: This means the study of soil morphology, its texture, consistence, depth, layers and physical properties of water. The aim is to know the quality of the location and its distinguishing features such as its landscape, the fauna and flora, shelters and resting places for migratory birds and animals etc.

3. Importance of different plant and animal species: They represent relative or competitive advantage from one area to the other.

4. Properties of natural shelters and their diversity: Here, it is important to know the fauna and the flora of each country, the locations they favor and the different ways that can be used to protect and preserve them in their natural habitats.

\section{Biodiversity}

The stability and sustainability of any ecosystem depend on biodiversity within this system.

1. Scarcity: Scarcity has three levels, local, regional and international. For example, at the local level, the Canadians divide Canada by means of maps (scale: 1:50000), each map represents an observation station. Plants and mammals are considered scarce if they are observed and recorded in less than 140 stations. For another group such as reptiles and fish, observation in less than 5 stations is considered as a measure of scarcity.

2. Area: The idea of geographical isolation confirms the fact that the greater the area of the protected area, the better, and the wider the area, the more the numbers of different species and the lesser the rate of their extinction. Some carnivorous animals and birds such as tigers and eagles require extensive areas of forest land to satisfy their daily needs.

3. Importance of the protected area for education and research: Education and research are one of the main reasons for establishing nature reserves. Availability of natural resources, means of transportation and facilities for educational purposes are essential in a protected area. Each location should also have a research center.

4. The aesthetic and cultural values of the location: The aesthetic value of the location is usually increased by the diversity of terrain, fauna and flora, water streams, high mountains and cliffs and other natural properties. They also include the distinguishing, cultural, artistic and historical features of the area.

5. Socioeconomic criteria: These include the revenue of tourism, job and investment opportunities, training, and the acceptance of the local community to the concept of protection. They also include the social and economic benefits that can be generated and their impact on raising the social standard of the local community, and achieving the recreational aims of visitors.

\section{ECOTOURISM PLANNING AND THE CHALLENGES OF TOURISM DEVELOPMENT IN ARCHAEOLOGICAL AREAS AND HISTORICAL SITES}

\section{Principles of ecotourism planning of archaeological and historical destinations}

The principles of ecotourism planning in archaeological and historical destinations are as follows (Ahmed, 1998; Nesreen, 2007):

Conservation of buildings and archaeological sites through:

1. Raising the practical value of the functionally neglected archaeological buildings by practicing tourist activities in them, and providing funds for their reservation and restoration.

2. Preserving the original functions of the archaeological buildings in use, so that the area does not lose its value.

3. Handling each archaeological building in accordance with its condition and its need of preservation, restoration and protection.

4. Removal of negative effects and encroachments on the archaeological sites.

5. Visual enhancement of the archaeological buildings and surrounding archaeological sites with protective walls. 
6. Controlling building activities in areas surrounding archaeological sites.

7. Preserving the privacy of residential areas, their social activities, customs, traditions and local culture by refraining from providing them with tourist services.

8. Preserving economic activities and abstaining from replacing them with tourist services.

Developing urban areas surrounding the archaeological sites by:

1. Controlling the use of land.

2. Controlling strategy and policy of development.

3. Handling causes of negative impacts such as overcrowding, air and visual pollution, etc.

4. Providing the area with the necessary infrastructure.

5. Ameliorating the social and economic framework.

Achieving the requirements of tourism development by means of:

1. Carrying out tourist projects in the area.

2. Gradual development of tourism by defining stages for tourism development in the area.

3. Encouraging the kind of tourism that conforms to the conditions of the archaeological sites, and giving members of the local community the opportunity to participate in the running of tourist services in the area.

\section{Challenges facing the rehabilitation projects of the archaeological areas}

Projects for the revival of archaeological sites confront many challenges which are not confined to a certain area but are common to all archaeological areas around the world. In most cases, it is not possible to separate these challenges as one challenge can generate another or aggravate its impact. Challenges facing projects for the revival and rehabilitation of archaeological sites are as follows (Waleed and Mansour, 2008).

\section{Organizational challenges}

These are great challenges because they are related to the area of land and its ownership. Archaeological sites had been founded a long time ago and conformed then to the environmental, social and cultural norms that were prevalent at the time of their construction. Now, they do not accord with the standards and trends of our modern age, or the suggested function after their restoration. Most archaeological sites lie in overpopulated districts similar to villages or small towns where ownership of land or buildings has become very limited.

Moreover, these sites are very old and it is improbable that they will be provided with the infrastructure necessary for modern development.

\section{Legal challenges}

These challenges result from lack of legislation to protect archaeological sites and their surroundings and prevent house owners from pulling down buildings unless they comply with the rules and regulations related to dilapidated houses. There are also no laws to prevent fragmentation of house or land ownership.

\section{Urban challenges}

These challenges are common in the archaeological areas that have not been entirely deserted. Sometimes, architectural elements that do not conform to the common architectural style of the area, such as concrete structures or modern building techniques, are introduced. Some archaeological areas have been encroached upon by randomly built houses, and parts of some archaeological buildings have been sacrificed to the bulldozer to develop the infrastructure, particularly roads.

\section{Social challenges}

When residents of archaeological areas found it difficult to meet all the requirements of their daily life in their old homes, they were driven to move to modern urban areas, and because of their ignorance of the cultural and archaeological value of their old homes, they left them in shambles or rented them to members of the lower middle class to practice their menial jobs in them. This eventually led to the degradation of important heritage sites.

\section{Economic challenges}

All the preceding challenges here mentioned accumulate and overlap in a way that makes possible solutions difficult in view of the fact that most countries do not provide the necessary funds for the conservation of old inestimable buildings in archaeological areas in addition to unawareness of the economic value of these archaeological areas, the revenue they can generate and the investment and job opportunities they can offer. Experience has shown that the participation of local communities in setting plans for the development and restoration of heritage areas is an important factor of success. Moreover, lack of knowledge of the economic benefits that can be reaped from developed and restored heritage areas discourages owners to participate in their conservation, restoration and sustainability.

\section{Types of land ownership in the heritage areas}

The common type of land ownership in the heritage areas is private ownership characterized by limited fragmentary 
plots that have passed from one generation to another according to laws of inheritance. Some plots of land are owned or have long ago been confiscated by the public sector. There are a few privately owned plots of land that are relatively large (Waleed and Mansour, 2008).

\section{LESSONS LEARNT FROM ARCHAEOLOGICAL AND HISTORICAL SITES}

Glimpsing some cases of development in heritage and historical sites, one can implicit the ability to overcome the previous mentioned challenges as follows:

1. To solve the problem of ownership we can see the shared responsibility as in:

i. Public Sector Ownership: The general sector undertakes development and offers parts of the heritage areas for investment. An example is the Kark Castle Square in Jordan.

ii. Public sector ownership developed by the private sector: The private sector hires a heritage building from the general sector, restores and rehabilitates it. Marrakech Museum in Morocco is an example.

iii. Joint ownership (private and general sectors): The heritage buildings or areas belong to the private sector, but the general sector undertakes development and then offers parts of the heritage area for investment. The Ji Heritage Village in the Patraa area in Jordan is an example.

iv. Joint ownership (local community and an investor): An investor contracts with local owners of a heritage area for development, and then offers parts of it for investment. Here, we have two distinguished cases, Tiba Zaman Hotel in Jordan and Warzazat Hotel in Morocco.

2. To achieve and make balance among legal, political and socioeconomic benefits: Some policies were formulated and consecutive procedures were taken in the aspects thus stated:

i. Creation of investment opportunities.

ii. Creation of job opportunities.

iii. Preserving the social order.

iv. Constraining social replacement

\section{EXPERIENCE OF AL-MOEZ STREET IN CAIRO}

\section{Problems of cultural heritage sites in Egypt}

As a result of rapid urban changes, urban heritage in Egyptian cities has been suffering serious problems for many years. These problems can be summed up as follows (www.annabbaa.org):

1. Disintegration of the traditional urban and social structure in the heritage sites.

2. Lack of maintenance of buildings.

3. Degradation of the infrastructure.

4. Continual social change which drove the original occupants to leave their homes to be replaced by people whose social, economic and cultural values are different and inferior.

5. Lack of the necessary tourist facilities to conserve heritage sites.

\section{Al-Moez Street: The case of this current paper as a reserve of world heritage sites}

Reserves of World Heritage are selected on account of their natural and cultural resources that are of global interest. They include areas containing relics of natural history, unique architectural heritage or mines. They also include areas that have rare plant or animal species (Hend, 2000).

Al-Moez Street is one of the important Islamic sites in Egypt. A variety of Islamic monuments and historical buildings are located herein. The area has had its name (Al-Moez Street) as affiliated with the Leader Al-Moez LiDeen Allah Al-Fatimi, who entered Egypt by $356 \mathrm{H} / 969$ A.D and then, Egypt was ruled by Al-Fatimi rulers. The street is considered as the greatest Islamic open air museum in the world. It is a panorama of Islamic, military, religious, social, educational and architectural monuments dated to consecutive Islamic states. Now, Al-Moez Street is an outstanding tourist attraction that is accessible to many flocks of visitors per day.

PROJECT OF DEVELOPING AL-MOEZ LI-DEEN ALLAH ALFATIMI STREET (Ragai et al., 2008: www.egypty.com; www.islamichistory.net; www.islamictourism.com) www.almersyoon.com;

\section{Brief historical background about efforts to develop the area}

Developing Fatimid Cairo began in 1993 as part of a comprehensive project to achieve sustainable development of Islamic and non-Islamic heritage sites in Egypt. Invaluable archaeological sites in the area were suffering remarkable degradation, restoration and rehabilitation work was a necessity to salvage them.

Studies on the area were made in collaboration with the United Nations Development Program, and the project was financed by the Egyptian Swiss Development Fund and many other Egyptian governmental bodies and ministries. In 1998, a plan to enhance the area was carried out. According to this plan, 34 archaeological monuments on both sides of the street from Al-Fotouh (Conquest) Gate to Zuwayla Gate were restored, in addition to 67 rare monuments adjoining the street. The $2^{\text {nd }}$ step was to develop the street itself by reconstructing the basic infrastructure.

\section{Reasons for carrying out the project}

The street was not on the tourist map of Cairo, so this great restoration project was carried out to include it as an important landmark of the city. 


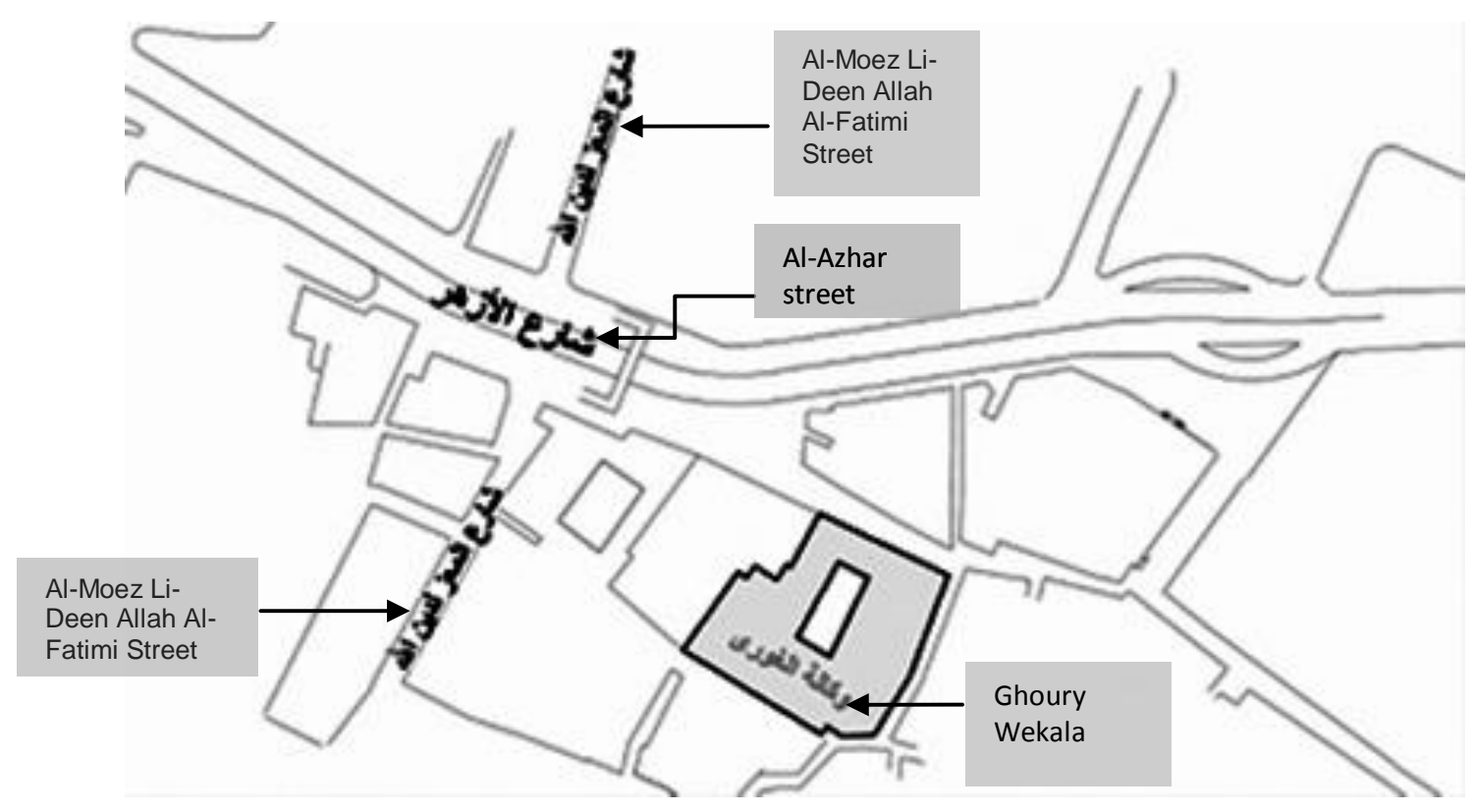

Figure 1. The layout of Al-Moez Li-Deen Allah Al-Fatimi Street.

\section{Aims of the project}

The project aims at restoring and developing Al-Moez Li-Deen Allah Al-Fatimi Street in view of the Islamic, military, religious, social, educational and architectural monuments it contains. It is a part of a comprehensive plan to restore and salvage 517 Islamic monuments that were partly damaged during 1992 earthquake (Figure 1).

\section{Importance of the project}

The project is of special importance because Al-Moez Street lies in the heart of the ancient historical part of Cairo. The Egyptian government regarded the salvage and restoration of Cairo's historical monuments as a national project worthy of meticulous care and attention. Therefore, 850 million Egyptian pounds were allotted for the execution of the project by the Ministry of Culture in collaboration with other ministries, the Governorate of Cairo and governmental bodies concerned.

\section{Measures taken}

1. Thirty-five million Egyptian pounds was spent on salvaging 135 monuments, including mosques, madrasas (schools), and Sabielkottabs. The project was expected to be completed and inaugurated in October 2008. The $1 \mathrm{~km}$ street will be a tourist attraction that opens only for pedestrians by day. Side streets and alleys will be accessible by means of stairs and ramps. At night, the street will be open for cars and commercial activities.

2. The infrastructure was rebuilt at the expense of the local administrative departments.

3. The Ministry of Culture has made integrated plans for the street in collaboration with local people. The local community has also contributed to the development and rehabilitation of some important historical Islamic buildings.
4. The street will be provided with electronic gates which can be opened in case of emergency during the day. It will also be provided with lavatories and tourist facilities.

5. Activities in the street should be compatible with its historical importance and on friendly terms with the environment that should be free from pollution, vibrations and inflammable materials.

\section{FIELD STUDY OF AL-MOEZ, LI-DEEN ALLAH AND AL-FATIMI STREETS}

Results of the study depended on the following:

1. Designing and distributing questionnaire forms to the authorities responsible and affiliated with development of the area.

2. Relatively half of the interviewed experts are man power in the departments of the Supreme Council of Antiquities and other authorities.

3. The study teamwork's field observation for the street.

4. Finding mean, standard Deviation and Standard Error of findings resulted from SPSS program. Moreover numeric values (Yes $=1$; $\mathrm{No}=2$ ) were given too.

\section{RESULTS OF THE STUDY}

\section{Based on interviewed experts}

Many specialists have been included such as the General Administrator of Islamic and Coptic Monuments in the Supreme Council of Antiquities.

\section{Criteria of declaration of reserves}

From the Table 1, it is clear that there is general agreement- 
since little dispersal among views of experts - that criteria of reserve declaration have been taken into consideration. With the main mean value being estimated as 1.00 , the standard deviation is less than one $(0.00)$. It may be said that the general mean degree is representative of the population so that the value of the standard error is exactly zero.

Aesthetic and urban dimensions and criteria have the first center. The value of mean is 1.10 . Socioeconomic dimensions and criteria came in the second position with an estimated mean degree of 1.20 , and political dimensions and criteria are the last one with a general mean value of 1.85 , which is near the "No alternative". These results are compatible with Dixon and Sherman (1997) who say that economic conditions and criteria precede the others.

The interviewed experts stated conflicted comments as follows:

1. Al-Moez Street is not a reserve, but is considered as a world heritage.

2. Development and restoration operations follow up reports are sent to the UNESCO. Moreover, a semi-year field visit to the area is carried out by a committee of the UNESCO.

3. The Egyptian Tourism and Culture Ministries declared that development and restoration responsibility of the area is wholly concise to them. So, the UNESCO's Office in Cairo abstained from conducting periodical, field, and inspective tours to the area since mid-year 2006.

\section{Criteria of preservation connected to monuments and historical buildings}

From Table 2, it is clear that there is a general agreement- since little dispersal among views of experts - on achievement of criteria of preservation affiliated with archaeological and historical buildings, except those concerning community-based tourism and participation of local community in tourism development. The main mean value estimated as 1.50 is near the "No" alternative and the mean degree of the Supreme Council of Antiquities is completely fitted with the "No" alternative with a score of 2.00. Meanwhile, the mean value of other authorities is estimated as 1.00 quite equal to the "Yes" alternative. This great dispersion is asserted by the standard deviation which is bigger than the one with a value of 2.23 .

The interviewed experts mentioned some comments on this part as follows:

1. Ameliorating function of heritage buildings of Al-Moez Street is in limited level and the restoration operations are funded from the Supreme Council of Antiquities in accordance with the law.

2. Coloring buildings to enhance the layout of heritage buildings of Al-Moez Street and to avoid the occurrence of visual pollution.

3. Zones of heritage buildings are matched up with their importance.

4. Privacy of residential areas is kept by increasing archaeological awareness among local people and refraining tourist facilities from taking place there.

5. The traditionally appealing economic activities are kept and the other activities are prohibited.

6 . Efforts to avoid or mitigate pollution are concise to prohibiting movement of vehicles through Al-Moez Street and get the traditional mills away from the area.

7. Availability and quality of infrastructure elements existed by changing sewage, electricity, and water networks.

8. The five-star restaurants and extension of tourist facilities to increase the time of tourist tours in Al-Moez Street are the outstanding proposed feasibility studies of tourism development in the area.

\section{Determinations and challenges of development in Al- Moez Street}

From Table 3, it is obvious that most of the answers are close to the "No" alternative, and it is assured with comprehensive agreement from respondents since there is determined dispersal among views of experts.

The interviewed experts mentioned some comments on this part as follows:

1. Land use obstacles are overcome in accordance with law.

2. Importance of issuing legislations of land uses and allowing activities in the area.

3. Necessity to strategic plan to control the overcrowding of people colonies in the area.

4. Replacement of local people by others is a great challenge of development in Al-Moez Street.

5. Determinations of funds are little, since the Egyptian Government is mainly responsible for managing sources of money for restoration and preservation of operations.

6. Other problems are caused by: dealing with people in the area during development operations; unawareness of the importance of enhancement the area; uncontrolled tourist visits to Al-Moez Street and intrusion on historical buildings and; some mills refusing the development of the area.

\section{Joint ownership among public sector, private sector, and local community}

Most of all the responses refer to the great role of the state and the modest efforts of the private sector and the local community of participation in restoration and development in the area. This is assured by statistical findings in Table 4. Most of them are near the "No" alternative (2). However, there are some historical entities owned by joint 
Table 1. Statistical findings of criteria concerned declaration of reserves.

\begin{tabular}{|c|c|c|c|c|c|}
\hline Item & Main mean & $\begin{array}{l}\text { Mean (The Supreme } \\
\text { Council of Antiquities) }\end{array}$ & $\begin{array}{c}\text { Mean of other } \\
\text { responsible authorities }\end{array}$ & $\begin{array}{l}\text { Standard } \\
\text { deviation }\end{array}$ & $\begin{array}{l}\text { Standard } \\
\text { error }\end{array}$ \\
\hline Criteria of reserve declaration have been taken into consideration. & 1.00 & 1.00 & 1.00 & 0.00 & 0.00 \\
\hline Political dimensions and criteria & 1.85 & 1.80 & 1.90 & 0.37 & 0.12 \\
\hline Socioeconomic dimensions and criteria & 1.20 & 1.20 & 1.20 & 0.41 & 0.13 \\
\hline Scientific dimensions and criteria & 1.35 & 1.40 & 1.30 & 0.49 & 0.16 \\
\hline Aesthetic and urban dimensions and criteria & 1.10 & 1.20 & 1.00 & 0.31 & 0.07 \\
\hline
\end{tabular}

Source: Based on the Study's SPSS Program

Table 2. Findings attributed to preservation of monuments and historical buildings.

\begin{tabular}{|c|c|c|c|c|c|}
\hline Item & Main mean & $\begin{array}{c}\text { Mean } \\
\text { (The Supreme Council } \\
\text { of Antiquities) }\end{array}$ & $\begin{array}{l}\text { Mean of other } \\
\text { responsible } \\
\text { authorities } \\
\end{array}$ & $\begin{array}{l}\text { Standard } \\
\text { Deviation }\end{array}$ & $\begin{array}{l}\text { Standard } \\
\text { Error }\end{array}$ \\
\hline Enhancement of practical value of functionally neglected heritage buildings & 1.45 & 1.40 & 1.50 & 0.51 & 0.17 \\
\hline Maintaining of archaeological buildings' original functions & 1.15 & 1.20 & 1.10 & 0.37 & 0.12 \\
\hline Refunction, maintenance, and restoration operations are unique and suitable for buildings & 1.15 & 1.20 & 1.10 & 0.37 & 0.12 \\
\hline Sacrifice to bulldozer any intrusions on archaeological areas & 1.10 & 1.20 & 1.00 & 0.31 & 0.07 \\
\hline Visual ameliorate of heritage buildings and surrounding areas & 1.20 & 1.20 & 1.20 & 0.41 & 0.13 \\
\hline Availability of zones for archaeological and historical buildings & 1.35 & 1.20 & 1.50 & 0.49 & 0.15 \\
\hline Controlling the architectural and land use operations close to the heritage area. & 1.55 & 1.40 & 1.70 & 0.51 & 0.16 \\
\hline Preservation of privacy of residential areas & 1.50 & 1.40 & 1.60 & 0.51 & 0.16 \\
\hline Maintaining of traditional economic activities & 1.15 & 1.20 & 1.10 & 0.37 & 0.12 \\
\hline $\begin{array}{l}\text { Recovering or mitigation of negative impacts resulted from traffic congestion and different } \\
\text { sources of pollution }\end{array}$ & 1.15 & 1.20 & 1.10 & 0.37 & 0.12 \\
\hline Providing elements of infrastructure & 1.10 & 1.10 & 1.10 & 0.31 & 0.10 \\
\hline Establishment of tourist projects & 1.20 & 1.10 & 1.30 & 0.41 & 0.13 \\
\hline Gradual tourism development & 1.25 & 1.20 & 1.30 & 0.44 & 0.14 \\
\hline Encouragement of community-based tourism & 1.50 & 2.00 & 1.00 & 2.23 & 0.50 \\
\hline
\end{tabular}

Source: Based on the Study's SPSS Program.

ownership.

\section{Expected socioeconomic benefits on local community}

Based on interviews with experts, new opportunities of employment are expected in the area.
The statistical findings presented in Table 5 point to more details about the agreement of respondents and reality of their answers. Most case studies represented in this current study show that socio-economic benefits are always taken into consideration in developing architectural and historical sites.

\section{Field observation}

The results depended on the visits of the team of the study to the area as scientific supervisors for the students of the Tourism Studies Department, Faculty of Tourism and Hotels, Fayoum University. They can be divided into two main 
Table 3. Findings of challenges of development operations in Al-Moez Area.

\begin{tabular}{|c|c|c|c|c|c|}
\hline Item & Main Mean & $\begin{array}{c}\text { Mean (The } \\
\text { Supreme Council } \\
\text { of Antiquities) }\end{array}$ & $\begin{array}{c}\text { Mean of other } \\
\text { responsible } \\
\text { authorities } \\
\end{array}$ & $\begin{array}{l}\text { Standard } \\
\text { Deviation }\end{array}$ & $\begin{array}{l}\text { Standard } \\
\text { Error }\end{array}$ \\
\hline Regulative obstacles of land ownership (private or public) & 1.35 & 1.20 & 1.50 & 0.49 & 0.15 \\
\hline Legislative obstacles concerning rules of land use and activities permitted in the area & 1.35 & 1.20 & 1.50 & 0.49 & 0.15 \\
\hline Architectural and urban problems of modern designs of buildings and uncontrolled urban extensions & 1.25 & 1.20 & 1.30 & 0.44 & 0.14 \\
\hline Challenges of replacement and settlement of strangers in the area and immigration of local people & 1.60 & 1.50 & 1.70 & 0.50 & 0.16 \\
\hline $\begin{array}{l}\text { Economic constraints connected to shortage of funds and absence of awareness of economic } \\
\text { benefits of development the area }\end{array}$ & 1.55 & 1.50 & 1.60 & 0.51 & 0.17 \\
\hline
\end{tabular}

Table 4. Findings of joint ownership.

\begin{tabular}{|c|c|c|c|c|c|}
\hline Item & Main mean & $\begin{array}{c}\text { Mean } \\
\text { (the Supreme Council } \\
\text { of Antiquities) }\end{array}$ & $\begin{array}{l}\text { Mean of other } \\
\text { responsible } \\
\text { authorities }\end{array}$ & $\begin{array}{l}\text { Standard } \\
\text { Deviation }\end{array}$ & $\begin{array}{c}\text { Standard } \\
\text { Error }\end{array}$ \\
\hline Public sector has ownership and development & 1.50 & 1.40 & 1.60 & 0.51 & 0.16 \\
\hline Public sector ownership and the private sector have responsibility of development & 1.90 & 1.80 & 200 & 0.31 & 0.07 \\
\hline Joint ownership and development of private and public sectors & 1.35 & 1.40 & 1.30 & 0.46 & 0.16 \\
\hline Joint ownership and development of private sector and community. & 1.60 & 1.60 & 1.60 & 0.50 & 0.16 \\
\hline
\end{tabular}

Table 5. Statistical findings connected with socioeconomic benefits.

\begin{tabular}{|c|c|c|c|c|c|}
\hline Item & Main mean & $\begin{array}{c}\text { Mean } \\
\text { (The Supreme Council of } \\
\text { Antiquities) }\end{array}$ & $\begin{array}{c}\text { Mean of other } \\
\text { responsible } \\
\text { authorities } \\
\end{array}$ & $\begin{array}{l}\text { Standard } \\
\text { deviation }\end{array}$ & $\begin{array}{l}\text { Standard } \\
\text { error }\end{array}$ \\
\hline Availability of jobs and mitigation of unemployment. & 1.30 & 1.30 & 1.30 & 0.47 & 0.15 \\
\hline Reducing rates of immigration outside the area. & 1.70 & 1.60 & 1.80 & 0.47 & 0.15 \\
\hline Extension of development zones and creating opportunities of investment & 1.25 & 1.30 & 1.20 & 0.44 & 0.14 \\
\hline $\begin{array}{l}\text { Maintaining of social strata and mitigation of social replacement of local people } \\
\text { in the area. }\end{array}$ & 1.35 & 1.40 & 1.30 & 0.49 & 0.16 \\
\hline
\end{tabular}

broad categories as follows:

\section{Disadvantages}

1. The air pollution resulted from cars of man power and the process of polishing the floor of $\mathrm{Al}$ Moez Street (Picture 3).

2. Until achievement of this study, there is shortage in providing infrastructure facilities to the area. (Example of facilities needed is in Picture 4). 3 . Some buildings have fractures and cracks
(Picture 7).

4. Problems are attributed to the visits of students to the street such as drawing, distortion of historical buildings.

5. Lack of notice boards guiding to and inside AlMoez Street. 
6. The overcrowding and density of residents on the both sides of the Al-Moez Street notwithstanding the fivemeter width of the street (Picture 1).

7. The improper behaviors of local people towards monuments Picture 8 , visitors and tourists coming to the area. For instance, they pull visitors over to buy souvenirs.

8. No space between most buildings and street.

9. Viewpoint of some experts who see burdens on converting Al-Moez Street to an Open-air Islamic Museum, because this requires evacuating local people and letting their residences to be sacrificed to the bulldozer.

\section{Advantages}

1. Some parts of Al-Moez Street are well developed. The best example is the area in the front of the Al-Hakim Mosque, where there are evergreen trees, pavement of street, lighted up buildings, etc. (Pictures 2 and 3 ).

2. Existence of a variety of shops that sell souvenirs affiliated with different historical eras and ages. This promotes the Egyptian Tourist Product (Picture 6).

3. The sparkling and fabulous scenery of the street in night which is based on underground lighting system (the responsible company stated in Picture 5).

4. Availability of traffic men and security guards in every place (Picture 6).

\section{CONCLUSION AND RECOMMENDATION}

From the previous display of the results affiliated with the Al-Moez area, we can say that the criteria and principles of the sustainability of urban and tourism development of Al-Moez Street have been taken into consideration to a reasonable extent. This is also confirmed by the findings of the statistical analysis and the positive and negative aspects that have been observed by a team who paid frequent visits to the area.

Moreover, based on Delphi Technique of the team's study, literature reviews and lessons benefited from case studies mentioned in this paper, and points of view affiliated with experts and specialists responsible for development and restoration at Al-Moez Street, the study can recommend some procedures to be taken at the area as follows:

1. The joint responsibility of restoration and development among all stakeholders interested in Al-Moez Street are as follows:

\section{a. The public sector}

(i.) Issuing legislations and rules regarding reservation in Al-Moez area.

(ii.) Setting quite urban master plans in the area.

(iii.) Empowerment to state administrative agencies to achieve aims of development in architectural and

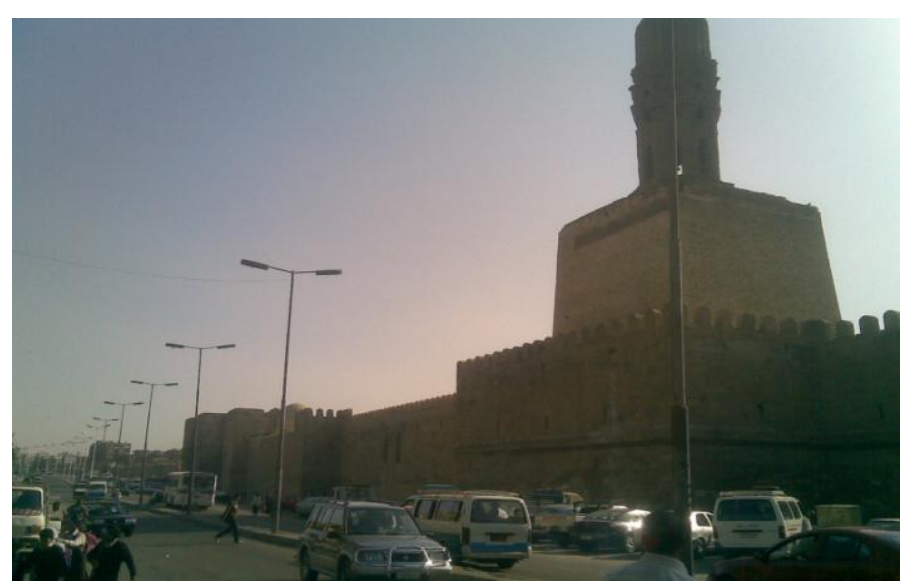

Picture 1. Old Wall of Cairo and Traffic Congestion Close to AlMoez Street.

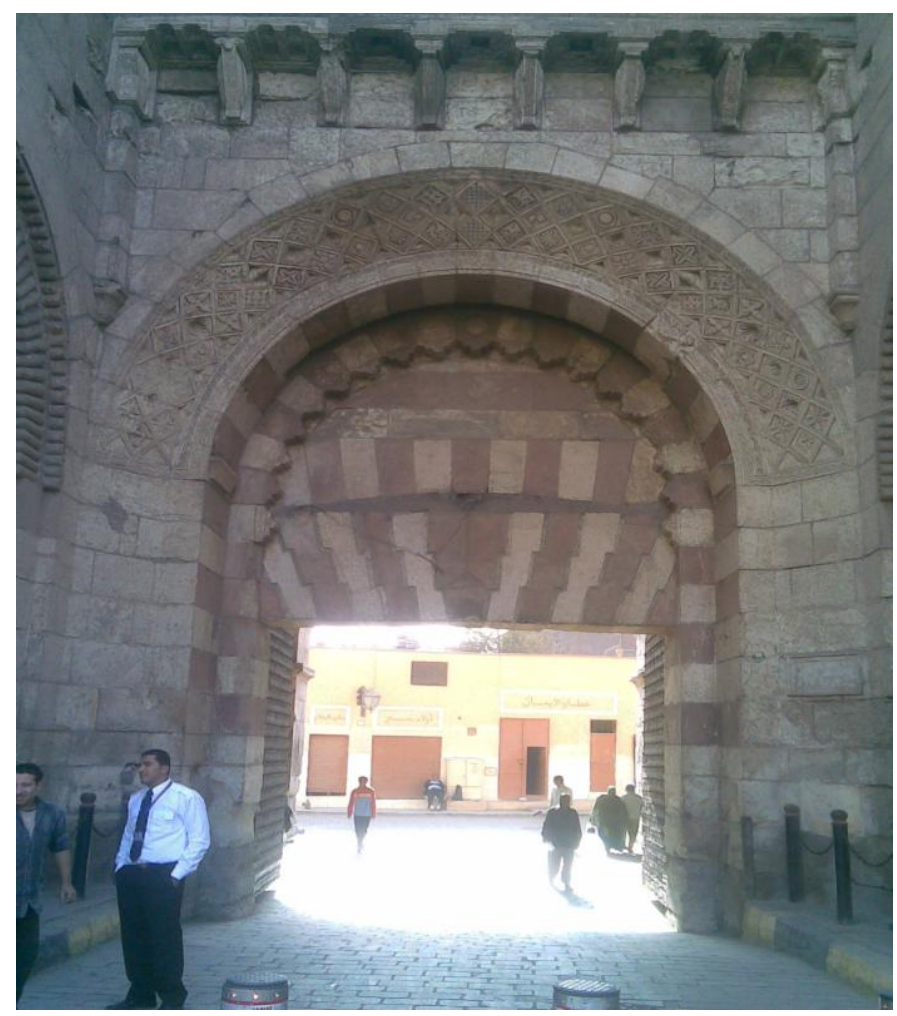

Picture 2. Development indicators at the beginning of Al-Moez Street (Al-Fotouh Gate).

historical areas of Al-Moez.

(iv) Provision of infrastructure and availability of basic facilities in the Al-Moez urban zone.

(v.) Conducting periodic programs of historical and architectural awareness for local people of Al-Moez.

(vi.) Encourage investment in development heritage sites in the street.

(vii.) Support private sector in marketing business of the site. 


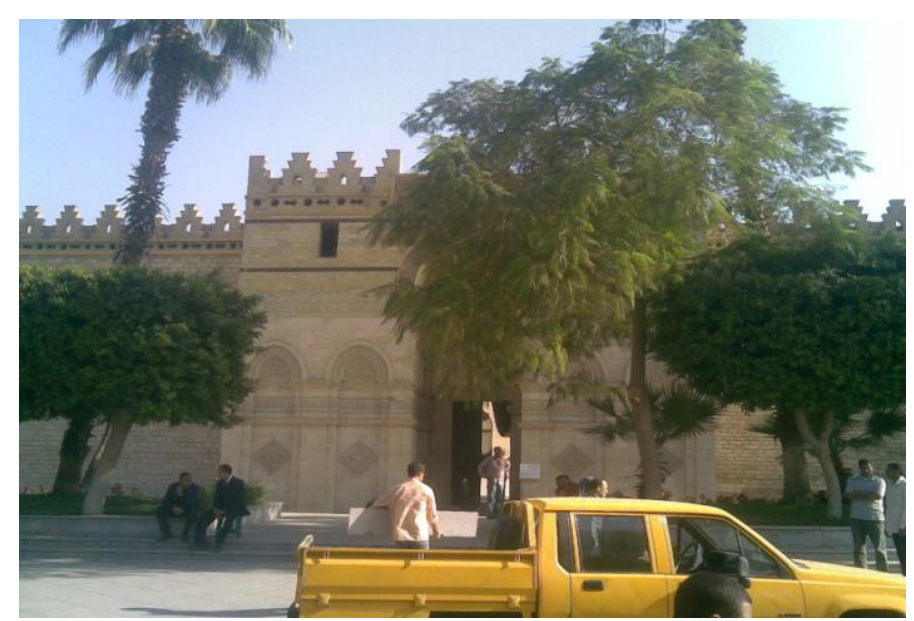

Picture 3. Development Signs in Front of Al-Hakim Mosque.

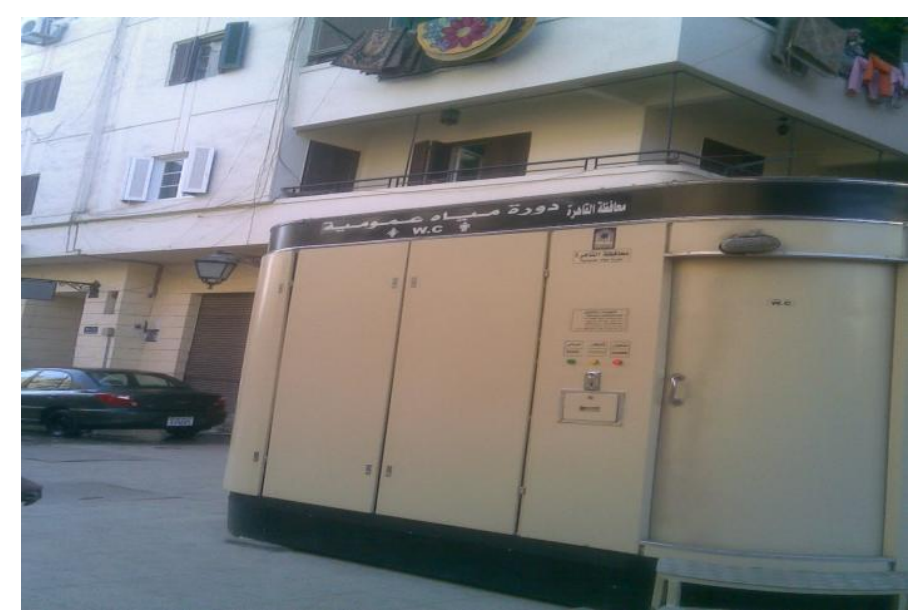

Picture 4. A public W.C. as a part of development in the area.

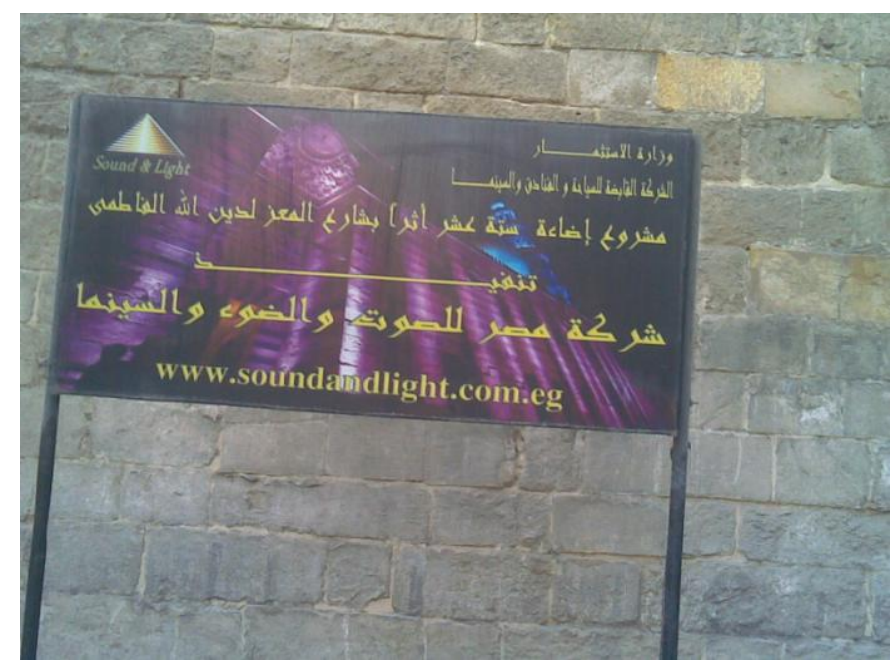

Picture 5. The responsibility of lighting historical buildings is empowered to Misr Company for Sound, Light and Cinema.

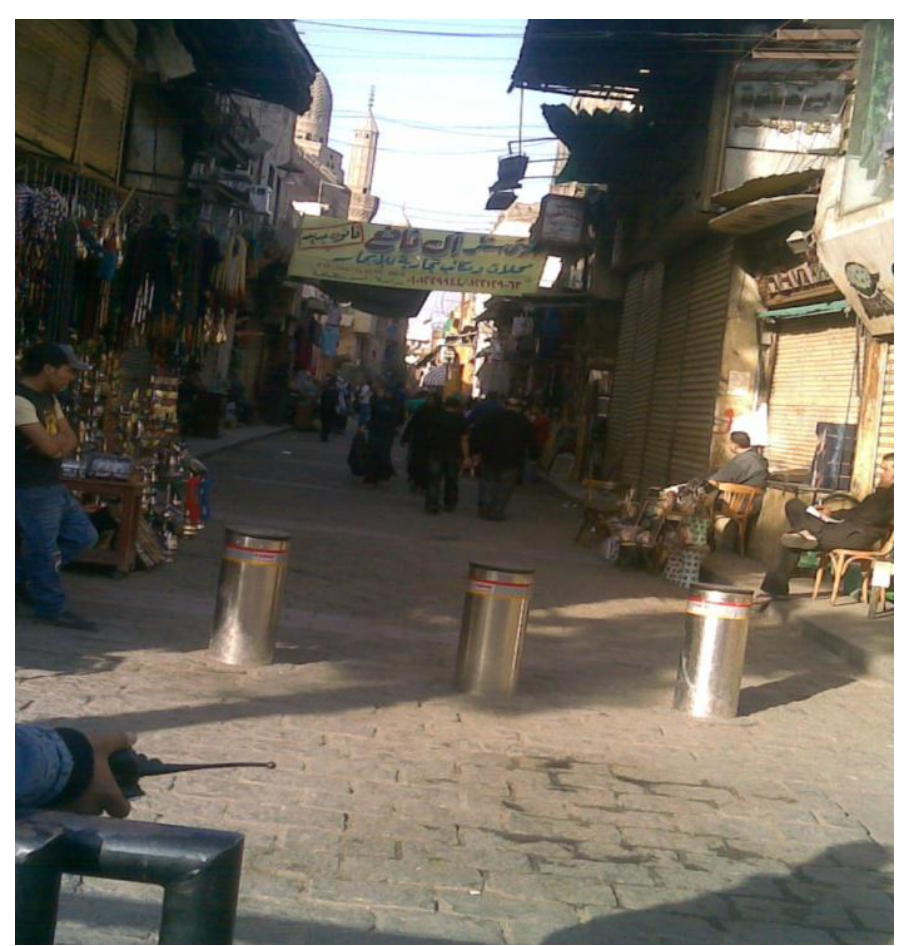

Picture 6. Instructions of traffic are outstandingly definite at AlMoez Street.

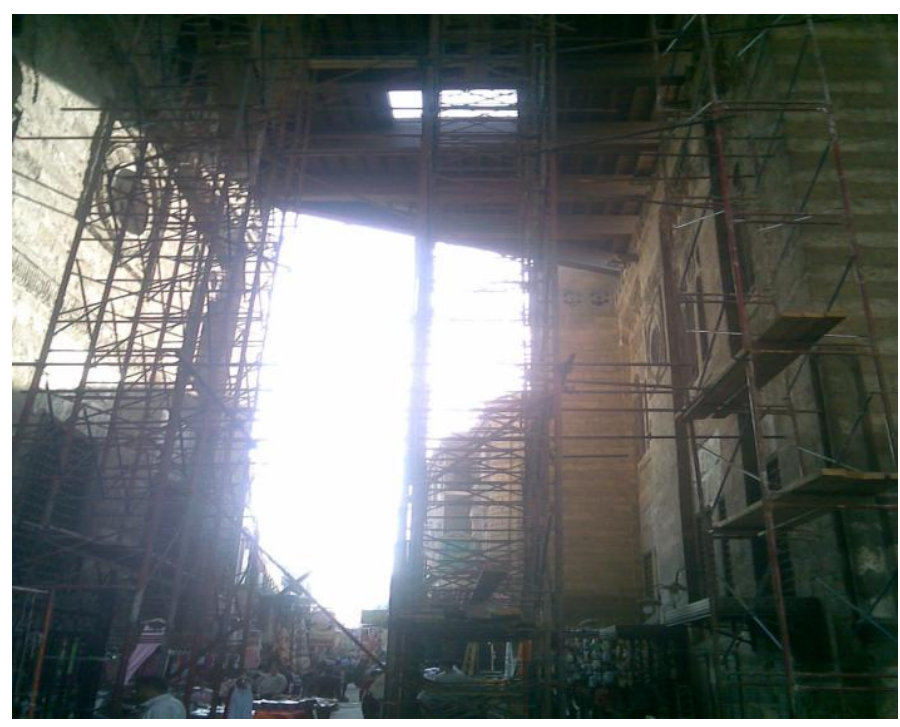

Picture 7. Restoration process of a Historical Building at Al-Moez Street.

b. The private sector

(i) Funding investment, restoration, and reuse projects of Al-Moez Street.

(ii) Formulating and implementing master plans and programs regarding the area. 


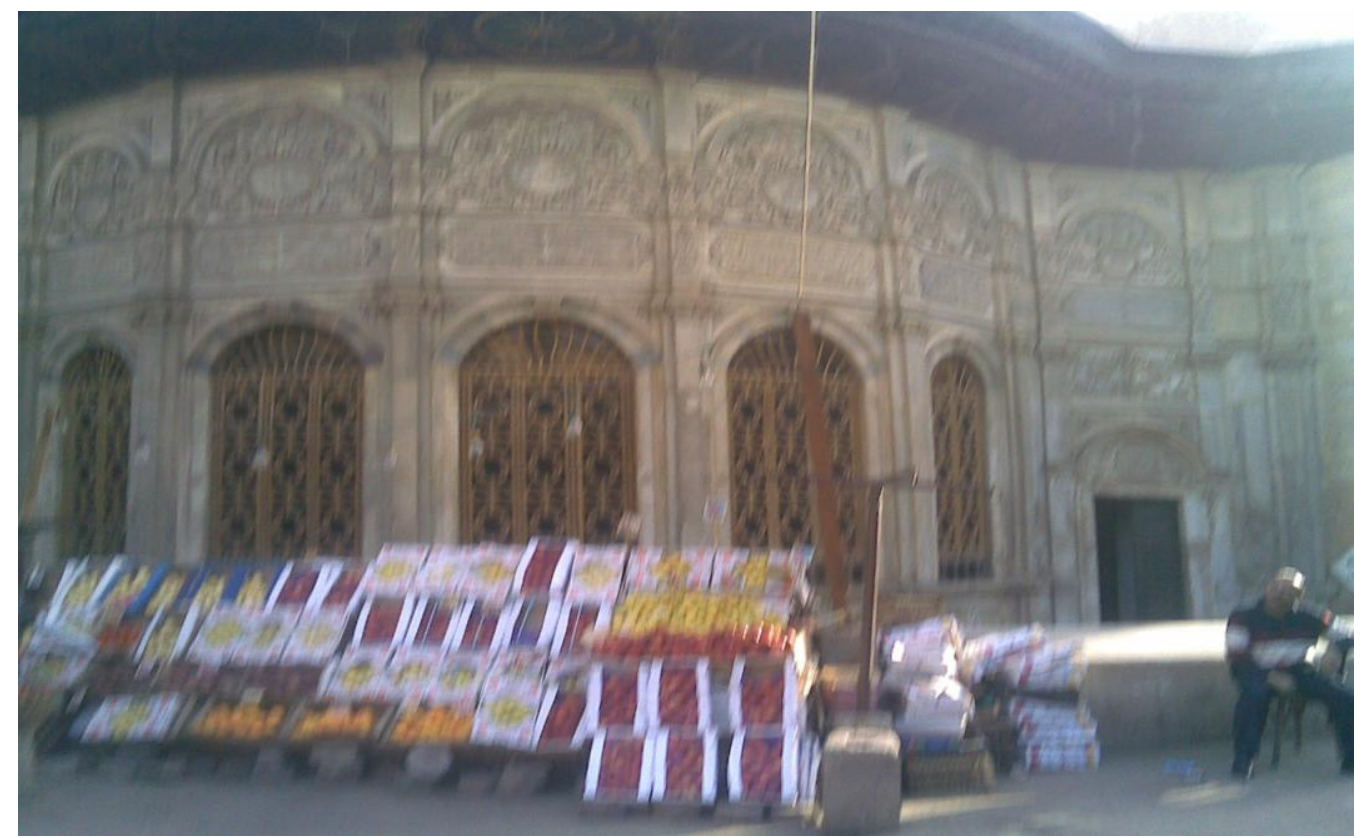

Picture 8. Selling a variety of fruits as an example of commercial activities in Al-Moez Street.

(iii) Stepping up efforts of promotion to the Al-Moez urban district.

2. Adopting total environmental value concept in the management of the Al-Moez area through:

1. Direct Use Value (DUV) refers to benefits that occur from direct use of the heritage assets in Al-Moez Street.

2. Indirect Use Value (IUV) is derived from the services that the heritage site provides, in addition to and separately from direct use value. Another meaning is the role which Al-Moez site plays in the production of a market commodity.

3. Option Value (OV) is the value obtained from retaining an option on the future Tourist use of Al-Moez Area.

4. Existence Value (EV) is the value conferred by survival of Al-Moez heritage site. This value is derived from the knowledge that something exists in the area. Thus, people place a value on preservation and restoration of distinguished heritage sites, even if they do not expect to see them. Existence value represents an attempt by the respondents to channel flows of value to others, about whom they care.

5. Bequest Value (BV) is the value of preserving Al-Moez heritage site for future generations. Bequest value is developed from knowledge that something is being passed on to one's descendants.

6. Discovery Value (DSV) is the unknown value of presently undiscovered dimensions of $\mathrm{Al}-\mathrm{Moez}$ architectural resource.

7. Non Human Value (NHV) is the value of Al-Moez heritage sites in their own right, distinct from their value to human society.
8. Altruism Value (AV) is the value which is based on the development of Al-Moez heritage sites, in the belief that other individuals than local people of the area, are able to enjoy experiencing these sites.

9. Private Opportunity Cost (POC) is the market value of opportunities foregone, as a result of restoration and development of significant archaeological sites in AlMoez area.

10. Social Opportunity Cost (SOC) is the total environmental value of opportunities foregone, including private, opportunity cost (POC), due to restoration and development of worthy archaeological sites of Al-Moez area.

11. Passive Nonuse Value (PNV) is the sum of bequest, existence, and altruism values.

$P N V=B V+E V+A V$

12. Use Value (UV) is the sum of direct use value, indirect use value, option value, and discovery value.

UV = DUV + IUV + OV + DSV

13. Total Economic Value (TEV) The sum of direct use value, indirect use value, option value, discovery value, bequest value, and existence values. It includes both use value and passive non-use value.

$T E V=D U V+I U V+O V+D S V+B V+E V$

14. Total Environmental Value (TNV) is the sum of nonhuman value and total economic value.

$\mathrm{TNV}=\mathrm{NHV}+\mathrm{TEV}$ 


\section{REFERENCES}

Ahmed EG (1998). "Tourist and Environmental Planning: Theory and Applications". Alam Al-Kootob, Cairo, Egypt. pp. 263-265.

Ragai H, Ayman M, Hussein A (2008): "Historical Cairo Development Project". Culture Ministry, Cairo, Egypt. pp. 23-45.

Ali AK (2008). "Cultural Tourism in Syria and Nowadays Challenges". Sanaa, Yemen. p.2.

Ali H (2001). "Tourism and Egyptian Environment", Cairo, Egypt. p. 79.

Ghada AA (2003). "Tourism and Environment". Lectures at Faculty of Tourism and Hotels, Fayoum University. pp. 185-187.

Ghada W (2007). "Natural Reserves in Egypt: Case Study on South Sinai". Ph.D. Thesis, Faculty of Tourism and Hotels, Fayoum University. pp. 23-34.

Hend N (2000). "Environmental Administration in Natural Reserves: Case Study of Ras Mohamed Reserve". Master Thesis, Faculty of Economics and Political Sciences, Cairo University, Cairo, Egypt. pp. 10-14.

Mohamed I (2007). "International Conference of Culture and Development'. Alexandria Bibliotheca, Alexandria, Egypt. pp. 23-35.
Nesreen RL (2007). "Tourism Planning in Heritage Sites: Evaluating of Environmental Impacts". First edition. Dar Al-Nile Publisher, Cairo, Egypt. pp. 10-24.

Waleed IK, Manssour AS (2008). "Integrated Urban and Tourist Planning in Heritage Sites". Tourism Supreme Authority, Saudi Arabia. pp. 2-6.

Dixon JA, Sherman PB (1997). Economics of Protected Areas: A New Look at Benefits and Costs. London: Earth Scan publications LTD. pp. 52-55.

Eagle PF (1984). The Planning and Management of Environmentally Sensitive Areas. London. pp. 67-73.

Ratcliff (1977). A Nature Conservation Review, Cambridge University, Press Cambridge. p. 261.

www.annabaa.org, accessed in October, 2008.

www.egypty.com, accessed in October, 2008.

www.islamichistory.net, accessed in October, 2008.

www.almersyoon.com, accessed in October, 2008.

www.islamictourism, accessed in October, 2008. 